\title{
Analisis Sikap dan Keyakinan Calon Guru di Indonesia terhadap Pemanfaatan Sejarah Matematika dalam Pembelajaran Matematika
}

\author{
Intan Bigita Kusumawati ${ }^{1}$, Achmad Dhany Fachrudin ${ }^{2}$ \\ ${ }^{1}$ STKIP PGRI Sidoarjo, bigita.intan@gmail.com \\ ${ }^{2}$ STKIP PGRI Sidoarjo, dh4nyy@gmail.com
}

\begin{abstract}
ABSTRAK
Tujuan dari penelitian ini adalah untuk menganalisis sikap serta keyakinan calon guru matematika mengenai penggunaan sejarah matematika dalam pembelajaran. Subjek dari penelitian ini adalah mahasiswa calon guru matematika dari Sembilan perguruan tinggi keguruan yang tersebar di Indonesia. Pengumpulan data dilakukan melalui pengisian angket sikap dan keyakinan penggunaan sejarah matematika dalam pembelajaran matematika. Item angket sikap dan keyakinan terdiri dari dua ketegori yaitu sikap dan keyakinan diri terhadap pemanfataan sejarah matematika serta sikap dan keyakinan terhadap kemampuan diri dalam memanfaatkan sejarah matematika. Analisis deskriptif kuantitatif digunakan untuk menganalisis angket sikap dan keyakinan. Hasil penelitian menujukkan bahwa sikap dan keyakinan pemanfaatan sejarah matematika secara keseluruhan berada pada level sedang, sementara keyakinan diri dalam menggunakan sejarah matematika dalam pembelajaran skornya masih rendah. Sikap dan keyakinan positif terhadap integrasi sejarah matematika dalam pembelajaran tersebut mengimplikasikan bahwa sebagian calon guru setuju bahwa sejarah matematika merupakan materi yang penting tidak hanya sebagai sebuah subjek materi tersendiri, namun sebagai subjek materi yang dapat terintegrasi dalam pembelajaran matematika.
\end{abstract}

Kata Kunci: sikap, keyakinan, calon guru, sejarah matematika, pembelajaran matematika

\begin{abstract}
This study aimed to analyze the attitudes and beliefs of prospective mathematics teachers regarding the use of mathematical history in learning. The subjects of this study were prospective mathematics teachers from nine colleges spread across Indonesia. The data collection was conducted by filling out the attitude and belief questionnaire of the use of the history of mathematics in mathematics learning. The items of attitude and belief questionnaire consisted of two categories; the first category is attitudes and beliefs regarding the use of the history of mathematics, and second is about self-efficacy to use the history of mathematics in learning. Quantitative descriptive analysis is used to analyze the attitude and belief questionnaire. The results showed that the attitudes and beliefs of the use of mathematical history are at a moderate level. On the other hand, the scores of selfefficacy in using the history of mathematics in learning is still low. A positive
\end{abstract}


attitude and belief in the integration of mathematical history in learning imply that almost all of the subjects in line with the argument that history of mathematics is a valuable material not only as a separate subject matter but as an integrated subject in mathematics learning.

Keywords: attitude, belief, prospective teacher, history of mathematic, mathemathic learning

\section{Pendahuluan}

Secara historis, banyak penemuan matematika yang bermanfaat dalam perkembangan ilmu pengetahuan baik secara langsung maupun tidak langsung. Penemuan atau proses penemuan dari matematikawan terdahulu tersebut digunakan sebagai dasar dalam pengembangan ilmu. Namun, di Indonesia masih sangat sedikit pemanfaatan sejarah matematika dalam pendidikan matematika siswa sekolah dasar atau menengah. Hal tersebut ditunjukkan dengan belum terintegrasinya pemanfaatan sejarah dalam kurikulum pendidikan matematika di Indonesia. Padahal jika dikaji secara mendalam, banyak sekali pencapaian besar dalam sejarah perkembangan konsep matematika yang dapat dimanfaatkan dalam pembelajaran matematika. Keung [1] menyebutkan bahwa pemanfaatan tersebut dapat berupa anekdot atau cerita dalam sejarah tersebut, broad outline (garis besar yang penting), content (materi) dan development of mathematical ideas (pengembangan gagasan matematika). Pemanfaatan sejarah ini memang tidak secara langsung membuat siswa sekejap memperoleh nilai yang tinggi, namun membuat pembelajaran matematika lebih bermakna bagi siswa [1].

Beberapa peneliti juga sangat merekomendasikan pemanfaatan sejarah matematika dalam pembelajaran [2-4]. Bentuk pengintegrasian tersebut dapat berupa pemanfaatan permasalahan dan pemecahannya yang diinspirasi dari sejarah matematika, pemanfaatan anekdot atau cerita dari sejarah untuk menginspirasi, pemanfaatan masalah-masalah dalam sejarah matematika sebagai sumber soal dan lain-lain. Bahkan, Fauvel [2] memberikan lima belas alasan pentingnya pemanfaatan sejarah matematika dalam pembelajaran. Dengan merangkum alasan tersebut, Fried [5] menyederhanakan alasan tersebut menjadi tiga hal pokok (1) bahwa sejarah matematika "memanusiakan" matematika, (2) sejarah matematika membuat matematika lebih menarik dan mudah dipahami, (3) sejarah matematika dapat memberi wawasan lebih dalam terhadap konsep, masalah dan pemecahan masalah dalam matematika.

Di samping penguasaan materi sejarah matematika yang cukup, pengintegrasian sejarah matematika dalam pembelajaran tentunya harus didukung dengan persepsi atau pandangan pendidik atau calon pendidik (calon guru) yang positif terhadap pemanfaatan sejarah matematika dalam pembelajaran. Pandangan tersebut diantaranya dapat diketahui dengan menganalisis sikap dan kepercayaan mereka untuk kemudian dapat diketahui, dipetakan kondisi riil mengenai bagaimana pandangan calon guru terhadap pemanfaatan sejarah matematika dalam pembelajaran. Oleh karena itu peneliti berkesimpulan sangat penting untuk melakukan penelitian analisis sikap dan keyakinan calon guru di Indonesia terhadap pemanfaatan sejarah matematika dalam pembelajaran matematika.

\section{Metode Penelitian}

Tujuan dari penelitian ini adalah untuk menganalisis bagaimana sikap dan keyakinan calon guru tersebut terhadap pemanfaatan sejarah dalam pembelajaran matematika. Jenis penelitian yang digunakan adalah penelitian kuantitatif desktiptif. 
Subjek dalam penelitian ini adalah calon guru matematika yang menempuh program pendidikan sarjana (S-1) di sembilan perguruan tinggi di Indonesia. pembagian subjek akan didasarkan pada tingkat atau level pendidikan dan jenis kelamin. level 1 adalah mahasiswa pada semester 1 dan 2, level 2 adalah mahasiswa semester 3 dan 4, level 3 adalah mahasiswa semester 5 dan 6 , level 4 adalah mahasiswa semester 7 dan 8 , sedangkan level 5 adalah mahasiswa yang menempuh pendidikan profesi.

Teknik pengumpulan data yang dilakukan pada penelitian ini adalah angket. Angket sikap dan keyakinan yang digunakan oleh peneliti adalah dengan mengadaptasi dari Alpaslan, Işıksal \& Haser [6]. Angket sikap dan keyakinan terhadap pemanfaatan sejarah matematika dalam pembelajaran matematika yang digunakan dalam penelitian ini bertujuan untuk menyelidiki sikap dan keyakinan calon guru terhadap pemanfaatan sejarah dalam pendidikan matematika. Sikap dan keyakinan diinvestigasi secara keseluruhan dalam instrumen ini. Jenis item penyataan dalam angket dikategorikan ke dalam dua kategori.Kategori pertama tentang sikap dan keyakinan terhadap pemnafaatan sejarah matematika dalam pembelajaran matematika. Kategori kedua tentang sikap dan keyakinan terhadap kemampuan diri memanfaatkan sejarah matematika dalam pembelajaran matematika. Bagian pertama dari angket atau kuesioner merupakan pertanyaan tentang demografi (misalnya, jenis kelamin, tahun tingkat dalam program pendidikan di universitas). Angket berisikan item penilaian sikap dan keyakinan yang merupakan angket dengan Skala jenis likert. Item-item ini diadaptasi dari angket yang diimplementasikan dalam studi penelitian terkait sejarah dalam pendidikan matematika yang dilakukan Marshal [7] ; Alpaslan, Işıksal \& Haser [6]. Angket terdiri dari 33 item pertanyaan dengan 5 opsi kategori respon, yaitu sangat setuju (5), setuju (4), ragu-ragu atau netral (3), tidak setuju, dan sangat tidak setuju (2) sehingga akan didapatkan skor responden antara 33 - 165. Waktu yang diberikan dalam pengisian kuesioner adalah 25 menit.

Untuk mengkategorikan level sikap dan keyakinan terhadap pemanfaatan sejarah matematika secara keseluruhan dari responden, skor total diklasifikasikan ke dalam tiga kategori yaitu; rendah, sedang, dan tinggi yang dijelaskan dalam tabel berikut

TABEL 1 Klasifikasi level sikap dan keyakinan

\begin{tabular}{lc}
\hline \multicolumn{1}{c}{ Level } & Rentang skor \\
\hline Rendah & $33-77$ \\
Sedang & $78-121$ \\
Tinggi & $123-165$ \\
\hline
\end{tabular}

Sedangkan pernyataan untuk setiap item dalam angket sikap dan keyakinan dikatakan positif jika persentase respon positif lebih dari sama dengan $70 \%$.

\section{Hasil Penelitian}

Angket sikap dan keyakinan pengunaan sejarah matematika mendapatkan tanggapan dari 349 responden calon guru matematika yang tersebar di sembilan perguruan tinggi di Indonesia. Responden terdiri dari 85,5 \% perempuan dan 14,5 \% lakilaki. Sebagian responden telah mengenal sejarah matematika selama masa perkulihan mereka. Lebih dari separuh $(62,2 \%)$ responden mendapatkan informasi tentang sejarah matematika yang berpotensi untuk dimanfaatkan dalam pembelajaran dengan belajar 
mandiri. Sementara itu hanya sebagian kecil responden yang aktif mengikuti publikasi tentang sejarah matematika dan pemanfaaatanya dalam pembelajaran.

TABEL 2 Demografi responden angket sikap dan keyakinan

\begin{tabular}{llr}
\hline \multicolumn{1}{c}{ Jenis } & \multicolumn{1}{c}{$\begin{array}{c}\text { Jumlah } \\
(\mathbf{\%})\end{array}$} \\
\hline Asal perguruan tinggi & Universitas Negeri Surabaya & 1,6 \\
& UIN Raden FatahPalembang & 32 \\
& STKIP PGRI Sidoarj & 2,8 \\
& Universitas Muhammadiyah Prof. Dr. Hamka & 33,3 \\
& IAIN Bukit Tinggi & 22 \\
& STKIP Andi Matappa & 10,6 \\
& Universitas KH. A. Wahab Hasbullah(UNWAHA) & 3,4 \\
& Universitas Muhammadiyah Jember & 20 \\
& Universitas Islam Majapahit & 5,2 \\
Lavel pendidikan & Level 1 & 0 \\
& Level 2 & 6,3 \\
& Level 3 & 0 \\
& Level 4 & 18,2 \\
& Level 5 & 0 \\
& Level 6 & 61,2 \\
Jenis Kelamin & Level 7 & 3,9 \\
& Level 8 & 10,4 \\
& Perempuan & 85,5 \\
& Laki - laki & 14,5 \\
\hline
\end{tabular}

Sebanyak 33 item penyataan angket sikap dan keyakinan dalam pemanfaatan sejarah matematika dengan 5 opsi kategori respon telah dianalisis. Skor total semua respon berkisar antara 33 sampai 165. Tabel dibawah menunjukkan analisis statistik deskriptif dari data yang telah diperoleh.

TABEL 3 Analisis statistik deskriptif data respons angket sikap dan keyakinan

\begin{tabular}{cc}
\hline Statistik deskriptif & Nilai \\
\hline Rata - rata (mean) & 119,94 \\
Standar deviasi & 12,07 \\
Skor terendah & 99 \\
Skor tertinggi & 158 \\
\hline
\end{tabular}

Dari analisis tabel di atas menunjukkan bahwa rata - rata skor angket adalah 119,94. Berdsarkan Tabel 1. kriteria level sikap dan keyakinan berada pada rentang $78-121$. Sehingga dapat disimpulkan secara keseluruhan sikap dan keyakinan calon guru matematika terhadap pemanfaatan sejarah matematika dalam pembelajaran adalah sedang. Secara keseluruhan tanggapan calon guru matematika tentang penggunaan sejarah matematika per item pernyataan disajikan dalam tabel dibawah ini

TABEL4. Persentase respon positif setiap item dalam angket sikap dan keyakinan

\begin{tabular}{|c|c|c|}
\hline No & Pernyataan & $\begin{array}{c}\text { Persentase sikap positif } \\
(\%)\end{array}$ \\
\hline 1 & $\begin{array}{l}\text { Sulit untuk mengintegrasikan sejarah matematika dalam } \\
\text { pendidikan matematika }\end{array}$ & 60,63 \\
\hline 2 & $\begin{array}{l}\text { Memiliki Pengetahuan tentang sejarah matematika } \\
\text { memberikan ide tentang pentingnya matematika dalam } \\
\text { kehidupan }\end{array}$ & 76,79 \\
\hline 3 & $\begin{array}{l}\text { Penggunaan sejarah matematika dalam pendidikan matematika } \\
\text { memberikan kontribusi positif pada pembelajaran matematika } \\
\text { yaitu memberikan sudut pandang dan cara penyajian suatu } \\
\text { materi tertentu }\end{array}$ & 76,90 \\
\hline
\end{tabular}




\begin{tabular}{|c|c|c|}
\hline No & Pernyataan & $\begin{array}{c}\text { Persentase sikap positif } \\
(\%)\end{array}$ \\
\hline 4 & $\begin{array}{l}\text { Menggunakan sejarah matematika dalam pembelajaran } \\
\text { matematika menyebabkan siswa kehilangan antusiasme } \\
\text { mereka untuk belajar matematika }\end{array}$ & 70,94 \\
\hline 5 & $\begin{array}{l}\text { Menyadari bahwa para matematikawan hebat juga pernah } \\
\text { membuat kesalahan (dalam matematika) dapat meningkatkan } \\
\text { motivasi siswa untuk pembelajaran matematika }\end{array}$ & 77,19 \\
\hline 6 & $\begin{array}{l}\text { Mempelajari sejarah matematika dapat memperkaya } \\
\text { pengetahuan para calon guru dalam menyiapkan pembelajaran }\end{array}$ & 80,34 \\
\hline 7 & $\begin{array}{l}\text { Calon guru harus diberikan kursus tentang bagaimana } \\
\text { menggunakan sejarah matematika dalam pendidikan } \\
\text { matematika }\end{array}$ & 76,61 \\
\hline 8 & $\begin{array}{l}\text { Sejarah matematika memungkinkan seseorang untuk } \\
\text { menghubungkan konsep-konsep matematika dan melihat } \\
\text { hubungan yang erat antar konsep tersebut }\end{array}$ & 75,98 \\
\hline 9 & $\begin{array}{l}\text { Sejarah matematika membuat siswa menyadari bahwa } \\
\text { matematika merupakan produk universal dari berbagai budaya } \\
\text { dan peradaban }\end{array}$ & 77,42 \\
\hline 10 & $\begin{array}{l}\text { Saya tidak memiliki gagasan tentang cara membelajarkan } \\
\text { suatu materi berbasis sejarah (misal, tangram, pembuktian } \\
\text { pythagoras, penggunaan ubin aljabar al khawarizmi dll) }\end{array}$ & 62.69 \\
\hline 11 & $\begin{array}{l}\text { Saya tidak tahu bagaimana mengintegrasikan sejarah } \\
\text { matematika ke dalam proses pembelajaran matematika }\end{array}$ & 61,14 \\
\hline 12 & $\begin{array}{l}\text { Pendidikan matematika yang terintegrasi dengan sejarah } \\
\text { matematika menampilkan gambaran yang lebih realistis dan } \\
\text { komprehensif atau menyeluruh tentang matematika itu sendiri }\end{array}$ & 73,63 \\
\hline 13 & $\begin{array}{l}\text { Masalah kehidupan nyata yang dipilih dari sejarah matematika } \\
\text { harus digunakan dalam pendidikan matematika }\end{array}$ & 72,32 \\
\hline 14 & $\begin{array}{l}\text { Sejarah matematika adalah media yang praktis untuk } \\
\text { pembelajaran matematika }\end{array}$ & 69,34 \\
\hline 15 & $\begin{array}{l}\text { Sejarah matematika harus diintegrasikan ke dalam pendidikan } \\
\text { matematika }\end{array}$ & 73,63 \\
\hline 16 & $\begin{array}{l}\text { Saya tidak memiliki cukup informasi tentang evolusi historis } \\
\text { konsep yang akan saya ajarkan di masa depan }\end{array}$ & 57,13 \\
\hline 17 & $\begin{array}{l}\text { Materi didaktis yang tertulis dan visual dapat dikembangkan } \\
\text { dengan integrasi menggunakan sejarah matematika (misalnya, } \\
\text { lembar kerja siswa, permainan, teka-teki, video dokumenter } \\
\text { dll) }\end{array}$ & 72,49 \\
\hline 18 & $\begin{array}{l}\text { Sejarah matematika membantu memahami peran dan } \\
\text { pentingnya matematika dalam kehidupan sosial bermasyarakat }\end{array}$ & 76,61 \\
\hline 19 & $\begin{array}{l}\text { Mengintegrasikan sejarah matematika dalam pembelajaran } \\
\text { matematika meningkatkan kecemasan matematika siswa }\end{array}$ & 65,61 \\
\hline 20 & $\begin{array}{l}\text { Pelibatan sejarah matematika dalam pendidikan matematika } \\
\text { mengganggu proses pembelajaran matematika }\end{array}$ & 70,20 \\
\hline 21 & $\begin{array}{l}\text { Sejarah matematika memungkinkan siswa untuk menemukan } \\
\text { kembali konsep matematika dengan memanfaatkan bakat dan } \\
\text { pengalaman mereka sendiri }\end{array}$ & 75,58 \\
\hline 22 & $\begin{array}{l}\text { Seandainya sejarah matematika diintegrasikan dalam } \\
\text { kurikulum pendidikan matematika pada sekolah akan } \\
\text { meningkatkan beban guru dan siswa }\end{array}$ & 61,71 \\
\hline 23 & $\begin{array}{l}\text { Investigasi sumber asli matematika memungkinkan guru dan } \\
\text { siswa untuk memperhatikan kelebihan matematika modern }\end{array}$ & 70,65 \\
\hline 24 & $\begin{array}{l}\text { Kegiatan pembelajaran berbasis sejarah matematika tidak } \\
\text { menarik minat siswa }\end{array}$ & 64,29 \\
\hline 25 & $\begin{array}{l}\text { Sejarah matematika membantu perubahan suasana } \\
\text { pembelajaran di kelas dari sekedar mentransfer pengetahuan } \\
\text { menjadi mengkontruksi pengetahuan }\end{array}$ & 72,72 \\
\hline
\end{tabular}




\begin{tabular}{clc}
\hline No & \multicolumn{1}{c}{ Pernyataan } & \begin{tabular}{c}
\multicolumn{1}{c}{ Persentase sikap positif } \\
(\%)
\end{tabular} \\
\hline 26 & $\begin{array}{l}\text { Kegiatan pembelajaran berbasis sejarah harus dimasukkan } \\
\text { dalam kurikulum pendidikan matematika }\end{array}$ & 67,90 \\
\hline 27 & $\begin{array}{l}\text { Calon Guru matematika harus memiliki pengetahuan gagasan } \\
\text { tentang perkembangan konsepkonsep matematika secara } \\
\text { historis }\end{array}$ & 75,87 \\
\hline 28 & $\begin{array}{l}\text { Sejarah matematika menjadikan kita lenih perhatian terhadap } \\
\text { kontribusi matematika pada disiplin ilmu lainnya (misalnya, } \\
\text { fisika) dan hubungan timbal baliknya }\end{array}$ & 72,20 \\
\hline 29 & $\begin{array}{l}\text { Perbandingan antara konsep matematika secara historis dan } \\
\text { modern membantu siswa memahami matematika }\end{array}$ & 73,81 \\
\hline 30 & $\begin{array}{l}\text { Saya tidak terpikir untuk melakukan kegiatan pembelajaran } \\
\text { yang berbasis sejarah matematika }\end{array}$ & 63,66 \\
\hline 31 & $\begin{array}{l}\text { Melakukan pembelajaran matematika berbasis sejarah } \\
\text { menyebabkan pemborosan waktu }\end{array}$ & 65,66 \\
\hline 32 & $\begin{array}{l}\text { Mengetahui perkembangan secara historis dari topik } \\
\text { matematika yang sedang dipelajari memungkinkan siswa } \\
\text { untuk mempelajari topik itu dengan lebih baik }\end{array}$ & 71,01 \\
\hline 33 & $\begin{array}{l}\text { Tidak penting untuk menggunakan atau mengintegrasikan } \\
\text { sejarah matematika dalam pelajaran matematika }\end{array}$ & 69.85 \\
\hline & \multicolumn{2}{l}{} \\
\hline
\end{tabular}

Dari 33 pernyataan tentang sikap dan keyakinan mahasiswa calon guru matematika terhadap pemanfaatan sejarah dalam pembelajaran matematika 12 pernyataan mendapatkan skor persentase positif di bawah 70\%. Analisis yang lebih mendalam tentang item pernyataan untuk tiap jenis pernyataan di sajikan dalam tabel berikut

TABEL5.Rata- rata persentase sikap positif per kategori penyataan angket

\begin{tabular}{clc}
\hline No & \multicolumn{1}{c}{ Jenis Pernyataan } & $\begin{array}{c}\text { Rata-rata persentase } \\
(\%)\end{array}$ \\
\hline 1 & $\begin{array}{l}\text { Sikap dan keyakinan terhadap manfaat } \\
\text { penggunaan sejarah matematika dalam } \\
\text { pembelajaran }\end{array}$ & 72,10 \\
\hline 2 & $\begin{array}{l}\text { Sikap dan keyakinan terhadap } \\
\text { kemampuan diri menggunakan sejarah } \\
\text { matematika dalam pembelajaran }\end{array}$ & 60,40 \\
\hline
\end{tabular}

Pada item pernyataan yang berkaitan tentang sikap dan keyakian pemanfaatan sejarah matematika dalam pembelajaran calon guru metamatika menunjukkan sikap dan keyakinan yang positif. Namun, pada item pernyataan yang terkait sikap dan keyakinan calon guru terhadap kemampuan dirinya untuk menggunakan sejarah matematika masih rendah. Hal ini dikarenakan mereka tidak tahu dan tidak punya ide bagaimana mengintegrasikan sejarah matematika dalam pembelajaran. Lemahnya pengetahuan dan pengalaman mengunakan sejarah matematika ini kemudian mendorong mereka kesulitan dalam mengapalikasikan penggunaan sejarah matematika dalam pembelajaran. Selanjutnya, hal tersebut menyebabkan level sikap dan keyakinan dalam pemanfaatan sejarah matematika secara keseluruha berada pada kategori sedang.

Hasil mengenai sikap dan keyakinan mahasiswa calon guru terhadap penggunaan sejarah adalah sesuai dengan penelitian di Turki yang menunjukkan bahwa mahasiswa calon guru umumnya memiliki sikap dan keyakinan yang positif tentang strategi pengajaran alernatif ini [8]. Sikap dan keyakinan yang positif inikemungkinan merupakan hasil dari mencari alternatif cara pembelajaran baru dalam pendidikan matematika ketika mempersiapkan diri menjadi guru matematika di masa depan. Namun, sebagian besar mahaiswa calon guru masih merasa mendapatkan sangat minim pengetahuan tentang 
penggunaan sejarah matematika selama masa perkuliahan. Sebagian besar informasi yang mereka dapat tentang penggunaan sejarah matematika dalam pembelajaran diperoleh melalui belajar secara mandiri.

Rendahnya sikap dan keyakinan terhadap kemampuan diri untuk menggunakan sejarah matematika dalam pembelajaran mahasiswa calon guru menunjukkan bahwa mereka lebih suka menggunakan sejarah dalam kegiatan pengajaran mereka di masa depan setelah mereka mendapatkan lebih banyak pelatihan atau pengetahuan yang berkaitan dengan pemanfaatan sejarah matematika dalam pembelajaran. Oleh karena itu, perguruan tinggi pencetak calon guru matematika harus mengambil keuntungan dari sikap dan keyakinan positif ini untuk memberikan lebih banyak pelatihan kepada calon guru tentang sejarah matematika dan penggunaannya dalam pengajaran matematika sekolah melalui mata kuliah tersendiri atau dalam kegiatan yang lain dalam program pendidikan guru matematika. Mata kuliah yang berkaitan dengan sejarah matematika selayaknya juga memberikan mahasiwa calon guru ide-ide tertentu tentang cara mengaplikasikan sejarah dalam pembelajaran. Sehingga mahasiswa calon guru di dapat mempertimbangkan sejarah matematika sebagai solusi alternatif dalam pengajaran mereka di masa depan dan semakin mengembangkan sikap dan keyakinan tentang kemampuan diri penggunaan sejarah di ruang kelas matematika.

\section{Kesimpulan}

Analisis sikap dan keyakianan calon guru matematika terhadap pemanfaatan sejarah matematika dalam pembelajaran secara keseluruhan berada pada level sedang. Meskipun item pernyataan yang terkait keyakinan diri untuk pemanfaatan sejarah matematika dalam pembelajaran masih relatif rendah namun item penyataan tentang sikap dan keyakinan untuk memanfaatkan sejarah matematika calon guru menunjukkan hasil yang positif. Hal ini dimungkinkan karena kurangnya pengetahuan mahasiswa calon guru yang mereka dapatkan selama perkuliahan tentang penggunaan sejarah matematika di ruang kelas. Sikap dan keyakinan positif mahasiswa calon guru serta banyaknya manfaat dari penggunaan sejarah matematika dalam pembelajaran [1-4] sudah seharusnya dimanfaatkan perguruan tinggi pencetak calon guru matematika untuk memberikan perhatian lebih dalam pengajaran sejarah matematika dan penerapanya selama perkuliahan.

\section{$5 \quad$ DaftarPustaka}

[1] Man-Keung, S. 2000. The ABCD of using history of mathematics in the (undergraduate) classroom. Paleontological Society Papers, 6, 3-10.

[2] Fauvel, J., \& Van Maanen, J. (Eds.). 2000. History in mathematics education. Dordrecht, the Netherlands: Kluwer Academic Publishers.

[3] Radford, L. \& Guerette, G. 2000. Second degree equations in the classroom: a Babylonian approach. In Katz, V. (Ed), Using history to teach mathematics: an international perspective (pp. 69-75). USA: The Mathematical Association of America. 
[4] Yuste, P. 2010. Learning mathematics through its history. Procedia-Social and Behavioral Sciences, 2(2), 1137-1141.

[5] Fried, M. N. 2001. Can mathematics education and history of mathematics coexist? Science \& Education, 10(4), 391-408.

[6] Alpaslan, M., Işıksal, M., \& Haser, Ç. 2014. Pre-service mathematics teachers' knowledge of history of mathematics and their attitudes and beliefs towards using history of mathematics in mathematics education. Science \& Education, 23(1), 159183.

[7] Marshall, G. L. 2000. Using history of mathematics to improve secondary students' attitudes toward mathematics (Doctoral dissertation, Illinois State University).

[8] Alpaslan, M., Isiksal, M., \& Haser, C. 2011. The development of attitudes and beliefs questionnaire towards using history of mathematics in mathematics education. In Proceedings of the seventh congress of the European society for research in mathematics education (pp. 1661-1669). 